\title{
Filmmaking 101
}

\section{Florida Atlantic University Libraries help produce a documentary}

\author{
by William Miller
}

B ecoming involved with the making of a documentary film is not standard operating procedure for an academic library, but when an independent filmmaker approached me about producing such a film, the project was too compelling to ignore, even though it required a daunting amount of private fundraising.

Filmmaker Al Barry had a lifelong obsession with the wooden synagogues of Eastern Europe. Before World War II there were more than 1,000 of them dorting the maps of Poland, Czechoslovakia, Latvia, Lithuania, and Russia-small, wooden synagogues built by local artisans, serving as the

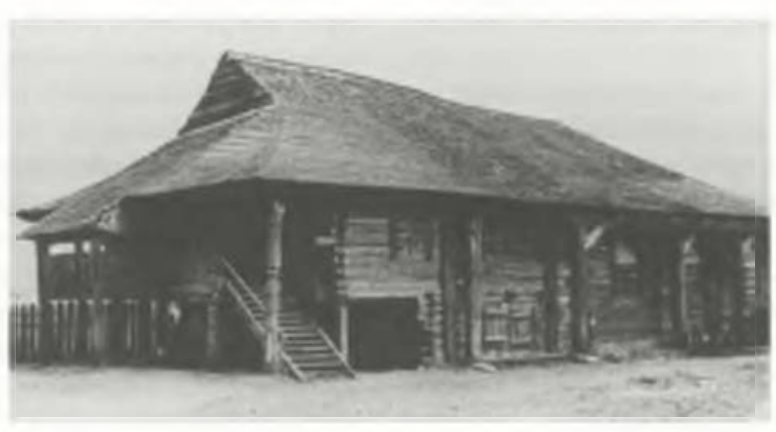

A pre-war glass negative photo of a wooden synagogue in Polaniec, Lithuania. built entirely of wood in a distinct architectural style and decorated inside with folk art, signs of the zodiac, and religious iconography. They stood for hundreds of years, serving the needs of their congregants, until the advent of the Nazis, who burnt or otherwise destroyed most of them, along with those who worshipped in them.

Barry's longtime dream was to travel to Eastern Europe to find out if any of these structures were still intact, and, if so, to film them inside and out.

He was impelled by the assumption that if any did still exist, they must have been close to collapse, so he wanted to find them and document them before they disappeared altogether. As an independent, Barry lacked the resources to pursue this project on his own, so he turned to Florida Atlantic University (FAU) for institutional support

Our library, with the largest collection of Judaica in the area, has a public outreach

\section{About the author}

William Miller is director of the Florida Atlantic University Libraries, e-mail: miller@fau.edu 


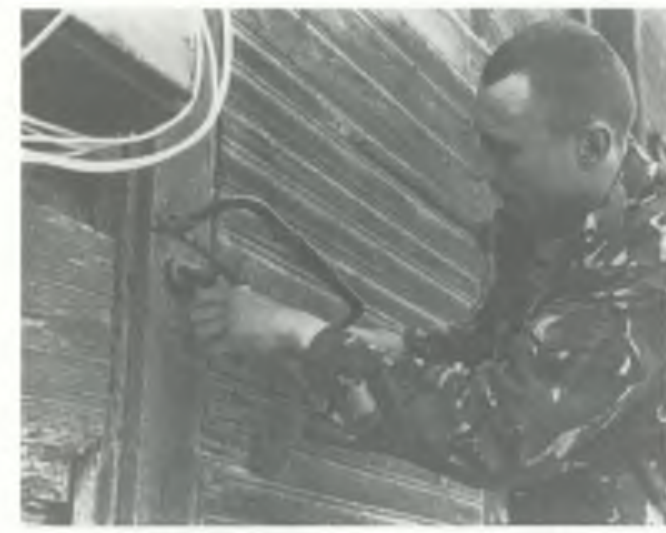

This local resident of Rozalimas, Lithuania, helps the Florida Atlantic University film crew get into a wooden synagogue by cutting a lock to which no one can find a key.

program, which has given us the recognition to make us a natural choice for someone with such a project.

Barry, a retired photograpiner for Life magazine, had already given us a collection of museum-quality models, which he had built over a 25 -year period, and there was no one in America more knowledgeable about these structures than he, so we had confidence that he was capable of carrying out this project.

However, no one really knew what he and the film crew would find if they went to Europe. He did have access to a cache of pre-war photographs of these structures (hidden from the Nazis and available to us for reproduction), so we had good records of what the buildings had looked like. But what did they look like now?

\section{Accepting the challenge}

After the war, with Eastern Europe closed to Westem eyes, these woxden structures were largely forgotten, and it was assumed that all had been destroyed.

After the break-up of the Soviet Union, however, a team from Hebrew University, traveling through Lithuania, found several of these wooden synagogues still intact, though falling apart and neglected; the team had been unable to enter any of the structures, so no one knew what the insides contained.

Barry convinced me that someone needed to step up to support this project, and FAU accepted the challenge. We ap- proached our major donors, and one couple was so intrigued with the project that they pledged $\$ 100,000$ towards its completion-not enough to cover all costs, but enough to give us the confidence that we could proceed, raising smaller amounts as we went along.

The library's development officer played a key role in enabling this project to go forward, as did the university's learning resources and public relations staff.

We engaged the award-winning videographer team of Kathy and Carl Hersh, who had done documentaries for PBS and the commercial networks.

The Hershes traveled to Lithuania and Latvia with Barry, filming the six wooden synagogues that we knew existed, and discovering and documenting four additional ones while they were there. The buildings that remain are all in very rural locations, and survive only because they were so remote that they were initially ignored, and were then put to other uses.

One question we had was how the local population would view the project. Because many people live in homes or on land which were "appropriated" from their original Jewish residents during the war, and previous visitors to small towns in Eastern Europe had found the locals fearful that the visitors' intent was to recover lost property, we wondered if the local inhabitants would obstruct our team's work. However, just the opposite occurred; the local residents were eager to help, and with their assistance, Barry was able to enter all of the structures and film their interiors and exteriors.

\section{What was inside}

Of course, our real hope was that we would find substantial reminders of these buildings' original purposes still intact when we gained access to the interiors. The reality was quite different, however. Barry and his team found the situation desolate. The wooden synagogues were not just rotting on the outside, they were also ruined within, filled with debris and clead animals, and with all traces of their past quite obliterated. What the Nazis had started, the Russians had finished, using these structures as pig barns, movie theaters, 
automobile garages, and equipment factories. All evidence of religious use was gone, except for one Jewish star built in above the window frame of one structure. and a small scrap of a wall poster in Yiddish in another. Neglect and the effects of the next few winters will put an end to all of these buildings. The Lithuanian and Latvian governments have designated several of these buildings as historic, but have no funds to repair or maintain them.

One interesting part of the film records Barry's discus-

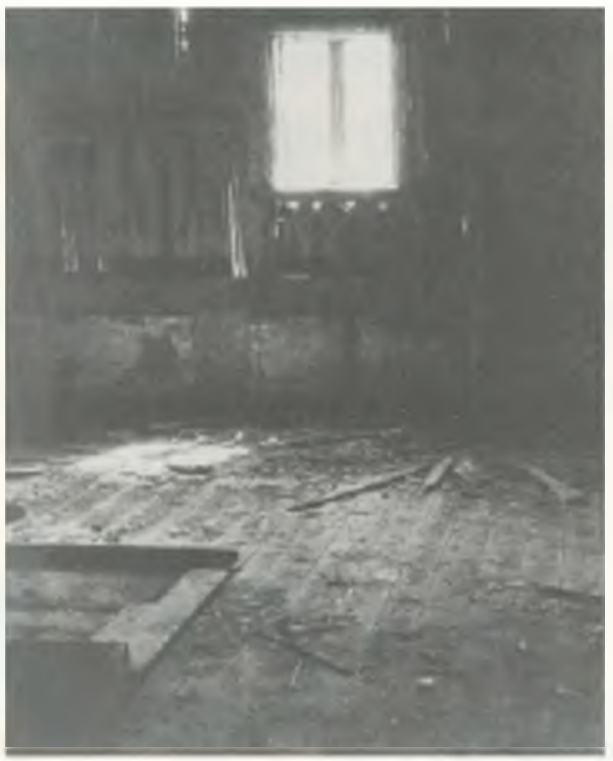

The interior of a wooden synagogue in Rozalimas, Lithuania. not only in English, but also in separate Hebrew and Yiddish versions. His sonorous voice adds much to the presentation.

Having completed the film in English, with the narration and music synchronized to the video, it turned out to be an enormous challenge to resynchronize with the Hebrew and Yiddish narrations, given the differences in the time-either longer or shorter-it takes to say things in different languages.

The technical assions with Lithuanian and Latvian officials in charge of the historic preservation of these synagogues; Barry had filmed more structures than they even knew existed.

\section{Finishing touches}

When Barry and the Hershes returned, they wrote the script and added to their original footage of the synagogues some pre-war film and photos of the same structures, both inside and outside; architectural plans; and a variety of background materials, including the discussions with local governmental officials and background information provided by our academic consultant, Henry Abramson, of FAU's Judaic Studies department.

The film features recollections by several former inhabitants of these small towns who now live in the United States. We had advertised in local papers and in publications geared to holocaust survivors for people with recollections of having worshipped in these structures, and we were stunned to have people come forward not just with recollections, but also with photographs and, in one case, film footage, which we were able to incorporate.

We commissioned an original musical score for the film and were fortunate to convince Theodore Bikel to do the narration- pects of completing the three versions took much longer than we had anticipated, giving us quite an appreciation for the complexities of filmmaking. The result is a 48-minute documentary, which has already won 3 awards and is selling quite nicely.

Most importantly, however, we were instrumental in establishing an historical record of these synagogues before the last of them rots away, and this film will exist as documentation of a whole world that has just about vanished.

Ironically, projects are now afoot to build full-scale replicas of these structures both in Berkeley, California, and in Amherst, Massachusetts, so the buildings will live on in new incarnations.

\section{Order your copy}

The film, "Lost Wooden Synagogues," can be purchased in VHS format for $\$ 29.95$. Send a check, made payable to the "FAU Foundation Library Account," to Florida Atlantic University Libraries, P.O. Box 3092, Boca Raton, FL 334310092. Specify English, Hebrew, or Yiddish version. 


\section{This is your opportunity to}

focus on the critical issues facing academic librarianship and higher education.

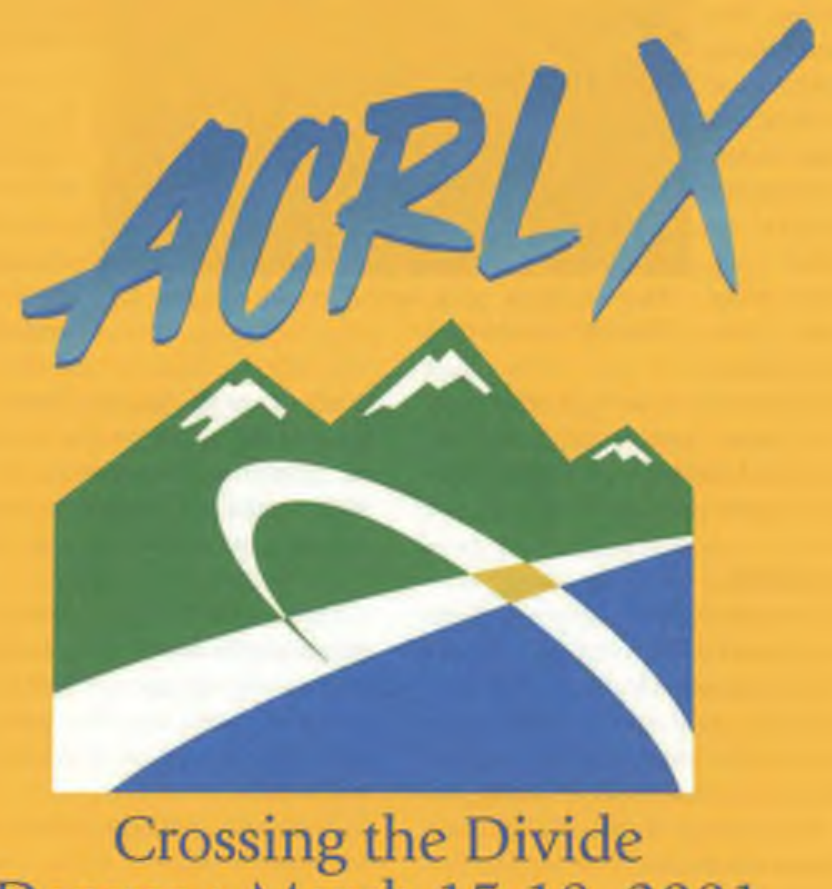

Denver $\Delta$ March 15-18, 2001

\section{Association of College \& Research Libraries}

A Division of the American Library Association

www.ala.org/acrl/denver.html e-mail: acrl@ala.org (800) 545-2433 ext. 2515 